\title{
Mycobacterium Tuberculosis-Associated Hemophagocytic Syndrome in Systemic Lupus Erythematosus: A Case Report
}

\author{
Sistemik Lupus Eritematözde Mycobacterium Tuberculosis ile \\ İlişkili Hemofagositik Sendrom: Olgu Sunumu
}

\author{
Hussein HALABI, ${ }^{1}$ Waleed HAFIZ, ${ }^{1}$ Mayadah BAWAYAN, ${ }^{1}$ Abdulghani MAULAWI, ${ }^{2}$ Hani ALMOALLIM ${ }^{3}$ \\ ${ }^{1}$ King Faisal Specialist Hospital and Research Center, Medicine, Jeddah, Suudi Arabistan \\ ${ }^{2}$ King Faisal Specialist Hospital and Research Center, Pathology, Jeddah, Suudi Arabistan \\ ${ }^{3}$ Umm Al Qura University, Medicine, Makkah, Suudi Arabistan
}

Mycobacterium tuberculosis infection is a complex, potentially life-threatening disease. Multiple hematological abnormalities may be seen in tuberculosis infection. However, Mycobacterium tuberculosis-associated hemophagocytic syndrome (HPS) in systemic lupus erythematosus (SLE) patients is quite rare. In this article, we report a 47-year-old female case of Mycobacterium tuberculosis-associated HPS in a patient with SLE. The patient had diffuse alveolar hemorrhage, myocarditis, and acute renal failure and required 17 sessions of plasma exchange and six sessions of cyclophosphamide. She also presented with fever, hypotension, desaturation, hepatosplenomegally, and pancytopenia which required intubation. Broncho-alveolar lavage revealed the diagnosis of Mycobacterium tuberculosis. The patient was initiated with rifampicin, ethambutol, pyrazinamide, moxifloxacin and amikacin. There was no indication of any SLE flare; however she continued to be febrile and pancytopenic. Her ferritin level was observed to be elevated. A bone marrow examination also showed hemophagocytosis plus multiple granulomas. Despite active treatment, the patient died due to septic shock and multi-organ failure. Mycobacterium tuberculosis has the potential to induce HPS in SLE patients; therefore, accurate diagnosis and aggressive therapy are critical. All SLE patients should be screened for latent tuberculosis and managed accordingly.

Key words: Hemophagocytic syndrome; systemic lupus erythematosus; tuberculosis.
Mycobacterium tuberculosis enfeksiyonu, kompleks ve muhtemelen yaşamı tehdit eden bir hastalıktır. Tüberküloz enfeksiyonunda birden çok hematolojik anormallikler görülebilir. Ancak, sistemik lupus eritematöz (SLE) hastalarında Mycobacterium tuberculosis ile ilişkili hemofagositik sendrom (HPS) nadir görülmektedir. Bu yazıda SLE olan ve Mycobacterium tuberculosis ile ilişkili HPS saptanan 47 yaşında bir kadın olgu sunuldu. Hastada difüz alveolar hemoraj, miyokardit ve akut renal yetmezlik vardı ve hastaya 17 seans plazma değişimi yapılması ve altı seans siklofosfamid verilmesi gerekti. Ateş, hipotansiyon, desatürasyon, hepatosplenomegali ve pansitopeni görülen hasta entübe edildi. Bronkoalveolar lavajda Mycobacterium tuberculosis tanısı kondu. Hastaya rifampisin, etambutol, pirazinamid, moksifloksasin ve amikasin başlandı. Sistemik lupus eritematozus alevlenmesine ilişkin herhangi bir endikasyona rastlanmadı; ancak, hastada ateş ve pansitopeni devam etti. Ferritin düzeyinin yükseldiği gözlendi. Kemik iliği muayenesinde hemofagositoz artı çoklu granüloma rastlandı. Aktif tedaviye rağmen, hasta septik şok ve çoklu organ yetmezliği nedeniyle kaybedildi. Mycobacterium tuberculosis, SLE hastalarında HPS'yi tetikleyebilir; bu nedenle bu hastalarda doğru tanı ve agresif tedavi önem taşır. Tüm SLE hastaları, latent tüberküloz için taranmalı ve gerektiğince tedavi edilmelidir.

Anahtar sözcükler: Hemofagositik sendrom; sistemik lupus eritematöz; tüberküloz.

\footnotetext{
Received: May 2, 2012 Accepted: July 15, 2012

Correspondence: Hussein Halabi, M.D. King Faisal Specialist Hospital and Research Center, Medicine, 21499 Jeddah, Suudi Arabistan.

Tel: 0096626677777 e-mail: mfasel@gmail.com 
Hemophagocytic syndrome (HPS) is a hematological phenomenon characterized by the activation of either macrophages or histiocytes that contain prominent hemophagocytosis features in the bone marrow and other reticulo-endothelial systems. This leads to the phagocytosis of white blood cells, red blood cells, platelets, and their precursors. Infections, malignancies, autoimmune diseases, and a variety of other medical conditions can all lead to HPS. ${ }^{[1]}$

In systemic lupus erythematosus (SLE) patients, HPS associated with Mycobacterium tuberculosis has only been reported once. ${ }^{[2]}$ Herein, we report a case of an SLE patient who developed HPS due to this type of bacteria.

\section{CASE REPORT}

A 47-year-old female was diagnosed with a case of SLE in November 2009 when she first presented with constitutional symptoms, a malar rash, and pancytopenia [whiteblood cell count $3 \times 10^{\wedge 9}\left(3.9-11 \times 10^{\wedge 9}\right)$, hemoglobin $8.5 \mathrm{~g} / 1$ (11-16 g/l), platelet $39 \times 10^{\wedge 9}$ (150$\left.400 \times 10^{\wedge 9}\right)$ ] along with positive antinuclear antibody (ANA), and anti-double-stranded DNA (anti-ds-DNA) antibodies. Her temperature was $36.9^{\circ} \mathrm{C}$, and her blood pressure was $74 / 45 \mathrm{mmHg}$. Furthermore, her heart rate was 108 beats/minute, and her respiratory rate was 20 breaths/minute. A chest examination revealed coarse crackles throughout both lungs as well as central and bilateral lung infiltration. The cardiac, abdominal, and neuromuscular exams were unremarkable. The patient was admitted to the intensive care unit (ICU) with diffuse alveolar hemorrhage and was started on pulse methylprednisolone, plasma exchange, and cyclophosphamide. She was also found to have severe mitral valve regurgitation, diffuse myocardial wall suppression, an ejection fraction of $25 \%$, and acute renal failure and received a total of 17 sessions of plasma exchange, three cycles of cyclophosphamide, and several sessions of hemodialysis. After this treatment in December 2009, her ejection fraction improved to $55 \%$, and her mitral valve regurgitation was found to be mild. She then underwent a renal biopsy that showed lupus nephritis class II (mesangial proliferation with mild-to-moderate fibrosis). She was also to complete a total of six cycles of cyclophosphamide every other week.

In February 2010, just a few hours after finishing her last cycle of cyclophosphamide, the patient came to the emergency department complaining of fever and lethargy. Her physical examination revealed an oral temperature of $38.4{ }^{\circ} \mathrm{C}$, blood pressure of $80 / 50 \mathrm{mmHg}$, heart rate of 110 beats/ min, respiratory rate of 18 breaths/min, and oxygen saturation of $96 \%$ at room air. Chest auscultation revealed coarse crackles, and abdominal palpation was notable for hepatosplenomegaly, which had not been found during her previous admission. She was resuscitated with intravenous fluids and started on broad-spectrum antibiotics plus hydrocortisone. Laboratory investigation showed the following: hemoglobin $10.5 \mathrm{~g} / \mathrm{l}$ (normal range 11-16 g/l), white blood cell count $1.48 \times 10^{\wedge 9}$ (normal range $3.9-11 \times 10^{\wedge 9}$ ) with neutrophils at $71 \%$, lymphocytes at $17 \%$, and monocytes at $6 \%$, platelet count $58 \times 10^{\wedge 9}$ (normal range $140-350 \times 10^{\wedge 9}$ ), lactate dehydrogenase $994 \mathrm{U} / 1$ (normal range 135-214 U/l), C-reactive protein (CRP) $273 \mathrm{mg} / \mathrm{l}$ (normal range 0-5 $\mathrm{mg} / \mathrm{l}$ ), erythrocyte sedimentation rate (ESR) $55 \mathrm{~mm} / \mathrm{hr}$ (normal range $<15 \mathrm{~mm} / \mathrm{hr}$ ), lactic acid $4.1 \mathrm{mmol} / \mathrm{l}$ (normal range $0.5-2 \mathrm{mmol} / \mathrm{l}$ ), alanine aminotransferase $147 \mathrm{U} / 1$ (normal range 10-45 U/1), and aspartate aminotransferase $87 \mathrm{U} / 1$ (normal range 10-45 U/l). The electrolytes and urea were normal. A chest X-ray showed widespread bilateral fine nodular shadows, but the patient had no symptoms and signs that indicated an SLE flare-up. Her C3 was $1.05 \mathrm{~g} / \mathrm{l}$ (normal range 0.9-1.8 g/l), and her $\mathrm{C} 4$ was $0.83 \mathrm{~g} / 1$ (normal range 0.1-0.4 g/l). In addition, the patient's anti-ds-DNA antibody titer was normal.

She was admitted to the ward after resuscitation. Thoracic computed tomography (CT) showed diffuse bilateral centrilobular lung nodules, paraaortic lymph node enlargement, and a small splenic lesion. By the next morning, the patient began to desaturate and required intubation. She was then moved to the ICU where she underwent a bronchoscopy, and a bronchoalveolar lavage sample was positive for acid-fast bacillus. The diagnosis of Mycobacterium tuberculosis infection was made, and she was started on rifampicin, ethambutol, pyrazinamide, moxifloxacin, and amikacin. All other cultures (blood and urine) were negative. Tests for brucella titer and hepatitis $\mathrm{B}$ and $\mathrm{C}$ were negative, and viral serology for cytomegalovirus (CMV), EpsteinBarr virus (EBV), and human immunodeficiency virus (HIV) also came back negative. Additionally, her fungal culture was also negative.

The patient, however, continued to be febrile and pancytopenic, and a suspicion of HPS was raised due to a ferritin level of $6.800 \mathrm{ug} / \mathrm{l}$ (normal range 15-150 ug/l). The patient underwent a bone marrow biopsy and aspiration which showed that her cellular 
marrow was infiltrated with abnormal histiocytes plus multiple granuloma consistent with hemophagocytosis (Figures 1 and 2). Therefore, HPS associated with Mycobacterium tuberculosis was diagnosed. Although she was on antituberculous medication and broadspectrum antibiotics, the patient developed septic shock and multi-organ failure which resulted in her death.

\section{DISCUSSION}

Although rare, HPS can occur in both active and inactive cases of SLE, but the majority take place during active SLE. Most instances of HPS in inactive SLE are thought to be related to immunosuppressive drugs, ${ }^{[3,4]}$ and several viral, bacterial, fungal, and parasitic infections have also been found to be associated with HPS.

Hemophagocytic syndrome is a potentially life-threatening, aggressive disease that manifests clinically with fever, lymphadenopathy, jaundice, hepatosplenomegaly, and bleeding tendency. Laboratory tests may show pancytopenia, elevated ferritin and lactate dehydrogenase levels, and disseminated intravascular coagulopathy (DIC). Diagnosis is confirmed by a bone marrow biopsy that shows hemophagocytosis. The mechanism of HPS is not well known. The immune complex deposits hematopoietic cells on the bone marrow and produces autoantibodies. These autoantibodies react with the hematopoietic cells, and then the histiocytes phagocytose these cells. Interleukin-1 (IL-1), tissue necrosis factors- $\alpha$ (TNF- $\alpha$ ) and interferon- $\gamma$ (INF- $\gamma$ ) are reported to be important for histiocyte activation

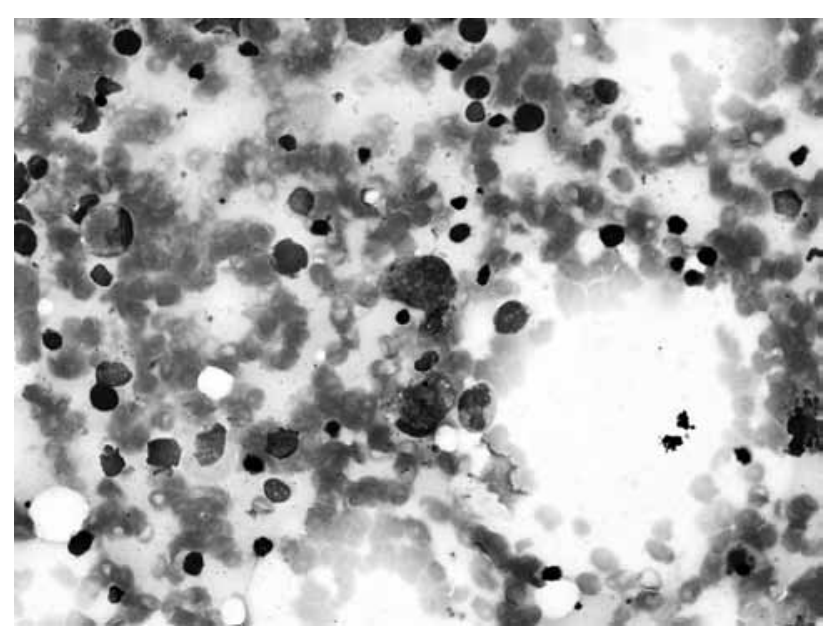

Figure 1. Bone marrow aspirate showing multiple hemophagocytic cells engulfing some erythroid cells, granulocytes, and platelets (Wright-Giemsa stain x 600 magnification). and the pathogenesis of HPS. ${ }^{[5,6]}$ When HPS is a manifestation of SLE, it is treated with high-dose corticosteroids. In one patient with SLE, plasma exchange was used for treatment of HPS. ${ }^{[7]}$ In addition, pathogen-directed therapy is indicated in HPS cases caused by infection. ${ }^{[4,5]}$

In patients with SLE, two cases of mycobacteria have been reported that were associated with HPS. The first case was a 15-year-old girl with SLE who was diagnosed with HPS associated with Mycobacterium avium complex (MAC). Her SLE was inactive, and she responded poorly to initial treatment with corticosteroids and intravenous immunoglobulins. However, following treatment with clarithromycin, amikacin, and ciprofloxacin, she improved gradually and was discharged. ${ }^{[5]}$ The second case, a 36-year-old woman, was initially thought to have acute lupus hemophagocytic syndrome. However, increased levels of CRP led to further investigation. A Ziehl-Neelsen stain of the buffy coat showed acid-fast bacilli in the phagocytic cells, and the diagnosis of HPS associated with Mycobacterium tuberculosis was confirmed by blood cultures and polymerase chain reaction. She died despite active treatment. ${ }^{[2]}$ Our case is the second case of HPS in inactive SLE caused by Mycobacterium tuberculosis. Our patient's characteristics were compared to the characteristics of the two patients in the preceding cases and are presented in Table 1.

As our case and a review of the literature demonstrate, HPS in SLE is an aggressive disease regarding both flare-ups and conditions related to infection. Mycobacterium tuberculosis should be considered in the differential diagnosis of the organisms

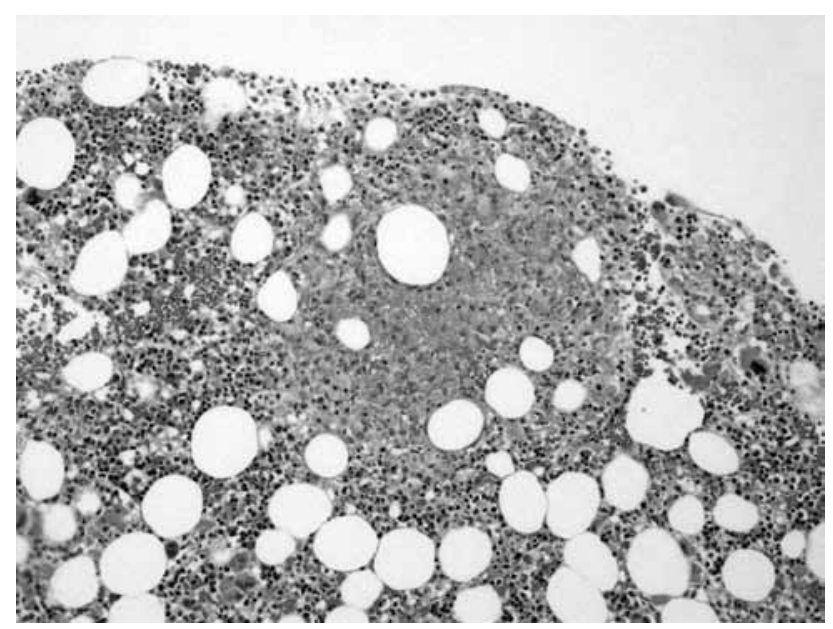

Figure 2. Bone marrow biopsy showing abnormal epitheloid granuloma with focal necrosis (H-E x 200). 


\begin{tabular}{|c|c|c|c|}
\hline Cases & Our case & Reference No. 5 & Reference No. 2 \\
\hline Age and gender & 47-year-old female & 15 -year-old female & 36-year-old female \\
\hline Clinical presentation & $\begin{array}{l}\text { Fever, hepatosplenomegaly, } \\
\text { pancytopenia, high ferritin level, } \\
\text { and chest infiltrates. }\end{array}$ & $\begin{array}{l}\text { Fever, hepatosplenomegaly, } \\
\text { pancytopenia, and high } \\
\text { ferritin level. }\end{array}$ & $\begin{array}{l}\text { Fever, lymphadenopathy, } \\
\text { and pancytopenia. }\end{array}$ \\
\hline Mycobacterial species & Mycobacterium tuberculosis & Mycobacterium avium complex & Mycobacterium tuberculosis \\
\hline $\begin{array}{l}\text { Method of diagnosis and } \\
\text { laboratory investigation }\end{array}$ & $\begin{array}{l}\text { Acid-fast bacilli in the } \\
\text { broncho-alveolar lavage. } \\
\text { Bone marrow showed } \\
\text { granuloma with } \\
\text { hemophagocytosis }\end{array}$ & $\begin{array}{l}\text { Bone marrow showed } \\
\text { non-caseating granulomatosis. } \\
\text { Mycobacterium avium } \\
\text { complex in gastric lavage. }\end{array}$ & $\begin{array}{l}\text { Hemophagocytosis and } \\
\text { acid-fast bacilli in the } \\
\text { peripheral blood smear. }\end{array}$ \\
\hline $\begin{array}{l}\text { Syndrome in } \\
\text { systemic lupus status }\end{array}$ & Inactive & Inactive & Inactive \\
\hline Treatment & $\begin{array}{l}\text { Rifampicin, ethambutol, } \\
\text { pyrazinamide, moxifloxacin, } \\
\text { and amikacin. }\end{array}$ & $\begin{array}{l}\text { Corticosteroids and IV } \\
\text { immunoglobulin initially, } \\
\text { then amikacin, ciprofloxacin, } \\
\text { and clarithromycin. }\end{array}$ & Not mentioned \\
\hline Outcome & Death & Discharge & Death \\
\hline
\end{tabular}

that can cause HPS in SLE. We recommend that any SLE patient should be examined for the presence of latent Mycobacterium tuberculosis prior to initiating immunosuppressive therapy, especially in endemic areas. In one study, it was found that the use of isoniazid prophylaxis in such patients decreased the incidence of tuberculosis from $11 \%$ to $2 \% \cdot{ }^{[8]}$ The published literature suggests that $\mathrm{T}$-cell interferon-gamma release assays (IGRAs) have a better diagnostic sensitivity to diagnose latent Mycobacterium tuberculosis than tuberculin skin testing (TST) in patients with immune-mediated inflammatory diseases. ${ }^{[9]}$ Once confirmed, accurate treatment should be strongly considered.

\section{Declaration of conflicting interests}

The authors declared no conflicts of interest with respect to the authorship and/or publication of this article.

\section{Funding}

The authors received no financial support for the research and/or authorship of this article.

\section{REFERENCES}

1. Botelho C, Ferrer F, Francisco L, Maia P, Mendes T, Carreira A. Acute lupus hemophagocytic syndrome: report of a case. Nefrologia 2010;30:247-51. doi: 10.3265/ Nefrologia.pre2009.Dic.5499.
2. Au WY, Kwong YL, Yuen KY. Hemophagocytosis in the peripheral blood due to tuberculosis mycobacteremia. Am J Med 2005;118:1298-9.

3. Okada M, Suzuki K, Hidaka T, Shinohara T, Kataharada $\mathrm{K}$, Matsumoto $\mathrm{M}$, et al. Hemophagocytic syndrome in systemic lupus erythematosus. Intern Med 2001;40:1263-4.

4. Papo T, Andre MH, Amoura Z, Lortholary O, Tribout B, Guillevin L, et al. The spectrum of reactive hemophagocytic syndrome in systemic lupus erythematosus. J Rheumatol 1999;26:927-30.

5. Yang WK, Fu LS, Lan JL, Shen GH, Chou G, Tseng $\mathrm{CF}$, et al. Mycobacterium avium complex-associated hemophagocytic syndrome in systemic lupus erythematosus patient: report of one case. Lupus 2003;12:312-6.

6. Takahashi K, Kumakura S, Ishikura H, Murakawa Y, Yamauchi Y, Kobayashi S. Reactive hemophagocytosis in systemic lupus erythematosus. Intern Med 1998;37:550-3.

7. Aoki A, Hagiwara E, Ohno S, Ueda A, Tsuji T, Ideguchi $\mathrm{H}$, et al. Case report of systemic lupus erythematosus patient with hemophagocytic syndrome, treated with plasma exchange, with specific reference to clinical profile and serum cytokine levels. Ryumachi 2001;41:945-50. [Abstract]

8. Gaitonde S, Pathan E, Sule A, Mittal G, Joshi VR. Efficacy of isoniazid prophylaxis in patients with systemic lupus erythematosus receiving long term steroid treatment. Ann Rheum Dis 2002;61:251-3.

9. Lalvani A, Millington KA. Screening for tuberculosis infection prior to initiation of anti-TNF therapy. Autoimmun Rev 2008;8:147-52. 